\title{
Infographic: Slow-release dexamethasone in proliferative vitreoretinopathy (PVR)
}

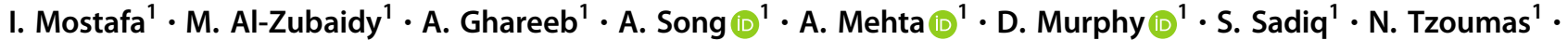 D. H. Steel $\mathbb{D}^{1}$}

Received: 20 March 2021 / Revised: 28 March 2021 / Accepted: 31 March 2021 / Published online: 2 June 2021

(c) The Author(s) 2021. This article is published with open access

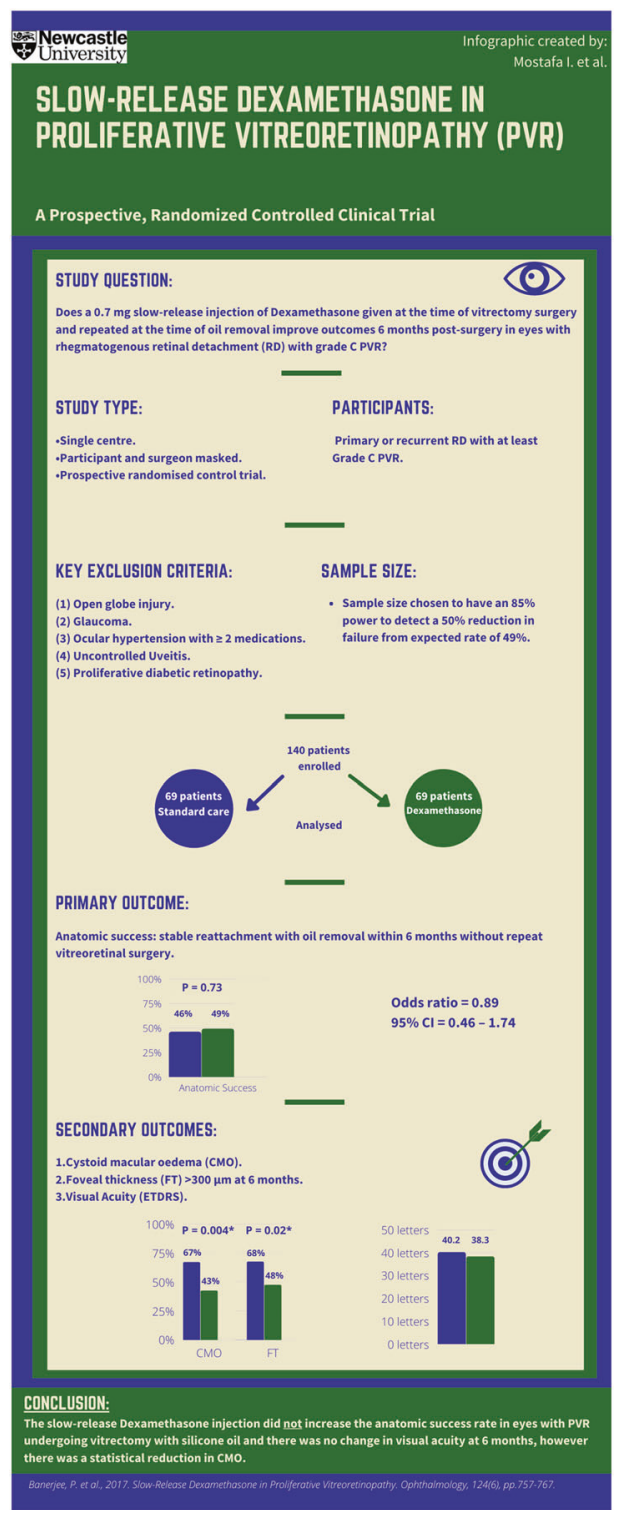

D. H. Steel

david.steel@ncl.ac.uk
Institute of Biosciences, Newcastle University, Newcastle upon Tyne, United Kingdom 
Fig. 1 The slow-release dexamethasone in proliferative vitreoretinopathy (PVR) prospective, randomized controlled clinical trial showed that a slow-release Dexamethasone injection given at the time of vitrectomy surgery and repeated at the time of oil removal does not increase the anatomic success rate at 6 months in eyes with rhegmatogenous retinal detachment with grade C PVR. There was also no change in visual acuity, however there was a statistical reduction in cystoid macular oedema. CI confidence interval.

Reference to original study: Banerjee, P. et al., 2017. Slow-Release Dexamethasone in Proliferative Vitreoretinopathy. Ophthalmology, 124(6), pp.757-767.

\section{Compliance with ethical standards}

Conflict of interest The authors declare no competing interest.
Publisher's note Springer Nature remains neutral with regard to jurisdictional claims in published maps and institutional affiliations.

Open Access This article is licensed under a Creative Commons Attribution 4.0 International License, which permits use, sharing, adaptation, distribution and reproduction in any medium or format, as long as you give appropriate credit to the original author(s) and the source, provide a link to the Creative Commons license, and indicate if changes were made. The images or other third party material in this article are included in the article's Creative Commons license, unless indicated otherwise in a credit line to the material. If material is not included in the article's Creative Commons license and your intended use is not permitted by statutory regulation or exceeds the permitted use, you will need to obtain permission directly from the copyright holder. To view a copy of this license, visit http://creativecommons. org/licenses/by/4.0/. 